\title{
Genetic Basis for the Hierarchical Interaction Between Tobamovirus spp. and L Resistance Gene Alleles from Different Pepper Species
}

\author{
Reiko Tomita, ${ }^{1}$ Ken-Taro Sekine, ${ }^{1}$ Hiroyuki Mizumoto, ${ }^{2}$ Masaru Sakamoto, ${ }^{1}$ Jun Murai, ${ }^{1}$ Akinori Kiba, ${ }^{2}$ \\ Yasufumi Hikichi, ${ }^{2}$ Kazumi Suzuki, ${ }^{1}$ and Kappei Kobayashi ${ }^{1}$ \\ ${ }^{1}$ Iwate Biotechnology Research Center, Kitakami, Iwate 024-0003, Japan; ${ }^{2}$ Laboratory of Plant Pathology \& Biotechnology, \\ Kochi University, Nankoku, Kochi 783-8502, Japan
}

Submitted 4 June 2010. Accepted 12 September 2010.

\begin{abstract}
The pepper $L$ gene conditions the plant's resistance to $T o$ bamovirus spp. Alleles $L^{1}, L^{2}, L^{3}$, and $L^{4}$ confer a broadening spectra of resistance to different virus pathotypes. In this study, we report the genetic basis for the hierarchical interaction between $L$ genes and Tobamovirus pathotypes. We cloned $L^{3}$ using map-based methods, and $L^{1}, L^{1 \mathrm{a}}, L^{1 \mathrm{c}}$, $L^{2}, L^{2 b}$, and $L^{4}$ using a homology-based method. $L$ gene alleles encode coiled-coil, nucleotide-binding, leucine-rich repeat (LRR)-type resistance proteins with the ability to induce resistance response to the viral coat protein $(\mathrm{CP})$ avirulence effectors by themselves. Their different recognition spectra in original pepper species were reproduced in an Agrobacterium tumefaciens-mediated transient expression system in Nicotiana benthamiana. Chimera analysis with $L^{1}$, which showed the narrowest recognition spectrum, indicates that the broader recognition spectra conferred by $L^{2}, L^{2 b}, L^{3}$, and $L^{4}$ require different subregions of the LRR domain. We identified a critical amino acid residue for the determination of recognition spectra but other regions also influenced the $L$ genes' resistance spectra. The results suggest that the hierarchical interactions between $L$ genes and Tobamovirus spp. are determined by the interaction of multiple subregions of the LRR domain of $L$ proteins with different viral $\mathrm{CP}$ themselves or some protein complexes including them.
\end{abstract}

Plant disease resistance operates through multiple mechanisms, including the pathogen-associated molecular pattern-

Current address for K. Kobayashi: Faculty of Agriculture, Ehime University, 3-5-7 Tarumi, Matsuyama, Ehime 790-8566, Japan.

Current address for M. Sakamoto: School of Life and Environmental Sciences, Osaka Prefecture University, Sakai, Osaka 599-8531, Japan.

Current address for J. Murai: Research Institute, Osaka Medical Center for Cancer and Cardiovascular Diseases, Osaka, Osaka 537-8511, Japan.

Current address for K. Suzuki: School of Environmental Science, University of Shiga Prefecture, Hikone, Shiga 522-8533, Japan.

Corresponding author: K. Kobayashi; E-mail: kappei@agr.ehime-u.ac.jp

Nucleotide sequence data is available in the DDBJ, EMBL, and GenBank data libraries under the following accession numbers: $L^{3}$, AB523370; $L^{1}$, $\mathrm{AB} 523372 ; L^{1 \mathrm{a}}, \mathrm{AB} 523373 ; L^{1 \mathrm{c}}, \mathrm{AB} 523374 ; L^{2}, \mathrm{AB} 523375 ; L^{2 \mathrm{~b}}$, AB523376; $L^{4}$, AB523377; and PIH-X, AB523371.

* The $e$-Xtra logo stands for "electronic extra" and indicates that five supplementary figures and two supplementary tables are published online. triggered immunity (PTI) and effector-triggered immunity (ETI). PTI is activated to a broad range of pathogens but is often suppressed by effectors that adapted pathogens produce. To combat the effector-driven virulence, plants have evolved disease resistance $(R)$ genes, which recognize effectors as avirulence (Avr) factors and direct ETI with a stronger resistance response (Chisholm et al. 2006; Jones and Dangl 2006).

A number of $R$ genes have been molecularly cloned and analyzed (Collier and Moffett 2009; Moffett 2009). The major class of $R$ genes codes for proteins with nucleotide-binding (NB) and leucine-rich repeat (LRR) domains and recognizes intracellular effectors. The C-terminal LRR domains of the NB-LRR protein have been shown to be major determinants of recognition specificity (Dodds et al. 2006; Rairdan and Moffett 2006; Shen et al. 2003). NB, together with the Apaf-1, R proteins, and CED-4 (ARC) domain (van der Biezen and Jones 1998) that lies between the NB and LRR domains, is thought to be a molecular switch that regulates activation of the $\mathrm{R}$ protein for resistance signal transduction (Collier and Moffett 2009; Moffett 2009; Rairdan and Moffett 2006). In addition to these domains, a number of $\mathrm{R}$ proteins have distinct $\mathrm{N}$-terminal domains. One major class of $\mathrm{R}$ protein $\mathrm{N}$-terminal domain is the toll/interleukin 1 receptor (TIR) cytoplasmic domain and the other class includes less-conserved coiled-coil (CC) domains that have one or more CC structures. $R$ genes with these $\mathrm{N}$-terminal domains are referred to as TIR-NB-LRR (TNL) class and CC-NB-LRR (CNL) class (Jones and Dangl 2006; McHale et al. 2006).

Use of cultivars containing $R$ genes is one of the best strategies for plant disease control because it is economical, laborsaving, and effective, unless resistance-breaking pathogens emerge. Unfortunately, the emergence of resistance-breaking pathogen strains is often encountered, which causes severe crop loss of resistant cultivars in the field. Therefore, it is important to molecularly identify the existing $R$ genes to study the molecular interactions and coevolution of $R$ genes and the pathogen's Avr effectors, and to explore or design new $R$ genes, with which we can control the pathogens that broke the existing resistance.

Pepper plants (genus Capsicum) have genes providing resistance against Tobamovirus spp., which are designated $L$ genes and have been introduced into pepper cultivars to protect the plants from Tobamovirus spp. infection. There are four $L$ gene alleles- $L^{1}, L^{2}, L^{3}$, and $L^{4}$ - known to provide increasing antiTobamovirus resistance: $L^{1}$ confers resistance to $\mathrm{P}_{0}$ pathotype viruses such as Tomato mosaic virus (ToMV); $L^{2}$ confers resistance to $\mathrm{P}_{0}$ and $\mathrm{P}_{1}$ pathotype viruses such as Paprika mild mot- 
tle virus (PaMMV) that overcomes $L^{1}$ resistance; $L^{3}$ confers resistance to $\mathrm{P}_{0}, \mathrm{P}_{1}$, and $\mathrm{P}_{1,2}$ pathotype Pepper mild mottle virus (PMMoV) that overcomes $L^{2}$ resistance; and $L^{4}$ confers resistance to $\mathrm{P}_{0}, \mathrm{P}_{1}, \mathrm{P}_{1,2}$, and $\mathrm{P}_{1,2,3}$ pathotype $\mathrm{PMMoV}$ that overcomes $L^{3}$ resistance (Boukema 1980, 1982, 1984). In addition to these classical $L$ genes, another allele with different temperature sensitivity, $L^{1 \mathrm{a}}$, was recently identified (Sawada et al. 2004). Because recent studies identified the $P_{1,2,3,4}$ pathotype of PMMoV, which broke the $L^{4}$ resistance (Antignus et al. 2008; Genda et al. 2007), there is an urgent need for $R$ genes effective against this virus.

Studies have identified the viral coat proteins (CP) as Avr effectors of $L$-gene-mediated resistance (Berzal-Herranz et al. 1995; de la Cruz et al. 1997; Gilardi et al. 2004; Matsumoto et al. 2008). Comparison of amino acid sequences revealed that CP of ToMV, PaMMV, and PMMoV are distantly related to each other but those from the $\mathrm{P}_{1,2}, \mathrm{P}_{1,2,3}$, and $\mathrm{P}_{1,2,3,4}$ pathotype PMMoV strains differ in only one or two amino acid residues (Antignus et al. 2008; Berzal-Herranz et al. 1995; GarciaLuque et al. 1993; Genda et al. 2007; Hamada et al. 2002; Tsuda et al. 1998). These facts support the idea that the interaction between $L$ genes and Tobamovirus spp. serves as a good system to study the mechanism and evolution of virus perception by plants.

We previously mapped the $L^{3}$ gene into a $400-\mathrm{kb}$ region of Capsicum chinense chromosome, which contained several copies of sequences homologous to the tomato $I 2$ vascular wilt resistance gene (Ori et al. 1997; Simons et al. 1998; Tomita et al. 2008). Based on these findings, we proposed some hypothetical models for the hierarchical interaction between $L$ genes and Tobamovirus pathotypes. In the first model, each of the allelic $L^{1}, L^{2}, L^{3}$, and $L^{4}$ genes encodes a single $\mathrm{R}$ protein with a broadening recognition spectrum whereas, in the second model, they represent increasing numbers of different R-protein genes, each of which confers resistance to one of the Tobamovirus pathotypes. In this report, we describe that the cloning and functional analysis of $L^{3}$ and its alleles, which encode the CNL class resistance proteins, support the first model for $L$ gene organization.

\section{RESULTS}

\section{Map-based cloning and characterization of the $L^{3}$ gene.}

We previously identified five BAC clones that encompass approximately $90 \%$ of the $400-\mathrm{kb} L^{3}$ region (Tomita et al. 2008). Nucleotide sequence analysis identified in those BAC clones only a single $L^{3}$ candidate that can encode a CNL class $\mathrm{R}$ protein homologous to the $\mathrm{I} 2$ protein (Fig. 1A and C; Supplementary Figs. 1 and 2). This gene, like $I 2$ (Simons et al. 1998 ) and $R 3 a$, a potato $I 2$ homolog conferring late blight resistance (Huang et al. 2005), does not contain any introns within the coding region but it does contain multiple introns, including long ones in both the $5^{\prime}$ and $3^{\prime}$ untranslated regions (UTR) (Fig. 1B). Seven other $I 2$ homologs in the $L^{3}$ region were pseudogenes. Another $I 2$ homolog with unknown function, $P I H-X$, was found in BAC clone $185 \mathrm{CA} 10$. It was found in a more distal part in the BAC clone than the 189D23M marker, which was segregated from $L^{3}$ resistance in a recombinant plant, relative to the above-mentioned $L^{3}$ candidate and the 21L24M marker, which has never been segregated from $L^{3}$ resistance. Therefore, it was thought to reside outside the $L^{3}$ region. The protein products of the $L^{3}$ candidate- $P I H-X, I 2$, and $R 3 a$-share high sequence identity and similarity with each other, while the C-terminal two-thirds of the LRR domains showed higher diversity than other regions (Fig. 1C).

To test whether the candidate gene is actually $L^{3}$, we examined its function in transient expression experiments in $\mathrm{Nico}$ - tiana benthamiana. When this gene was expressed alone, via agroinfiltration and under the control of the Arabidopsis thaliana actin 2 promoter (using a binary vector named $\mathrm{pBAL}^{3}$ ), no response was observed (Fig. $1 \mathrm{D}, L^{3}$ ). In contrast, when coexpressed with the PMMoV-Iw strain (PIW) genome, local hypersensitive reaction (HR) lesions were observed. The virus clone itself did not induce the HR (Fig. 1D, $\beta$-glucuronidase [GUS]+PIW versus $\left.L^{3}+\mathrm{PIW}\right)$. HR was also observed when the gene was coexpressed with Tobamovirus CP (Fig. 2D) (discussed below). Immunostaining of agroinfiltrated tissue with an anti-PMMoV antibody revealed the restriction of virus spread by the candidate gene (Fig. 1E). The $L^{3}$ candidate was stably introduced into $N$. tabacum plants and tested for resistance to ToMV because $N$. tabacum is barely susceptible to PMMoV. Three $\mathrm{T}_{1}$ plants each from four and 13 transgenic lines transformed with pBA empty vector (pBA-ev) and $\mathrm{pBAL}^{3}$, respectively, were tested for transgene expression (Supplementary Fig. 3) and resistance to ToMV. All of the control lines were susceptible but $L^{3}$-expressing lines were resistant to ToMV as judged by the lack of virus spread to the uninoculated upper leaves (Fig. 1F). However, unlike in the original Capsicum plants and in the transient expression assay, no visible HR symptoms were observed on the inoculated leaves, despite HR being induced in the transient assay in $N$. tabacum (Fig. 1G). These observations suggest that overexpression of the $L^{3}$ candidate can confer extreme resistance, as reported for $H R T$ and $R C Y-1$, allelic resistance genes of $A$. thaliana to Turnip crinkle virus and Cucumber mosaic virus (Cooley et al. 2000; Sekine et al. 2008). It is still not clear whether or not ToMV replicated in the inoculated leaves of the transgenic lines because the detection method is not suitable for examining virus replication in a single cell or a small number of cells. Therefore, other experimental systems should be employed for elucidating the mode of ToMV resistance in the $L^{3}$-expressing transgenic tobacco.

C. chinense plants harboring $L^{3}$ are resistant to ToMV, PaMMV, and the $\mathrm{P}_{1,2}$ pathotype of PMMoV but are susceptible to $\mathrm{P}_{1,2,3}$ and $\mathrm{P}_{1,2,3,4}$ pathotypes of PMMoV (Antignus et al. 2008; Boukema 1980; Genda et al. 2007). To test whether the $L^{3}$ candidate conditions all these interactions by itself, it was coexpressed with different Tobamovirus CP (Table 1). When coexpressed with $\mathrm{P}_{0}, \mathrm{P}_{1}$, or $\mathrm{P}_{1,2} \mathrm{CP}$, the $L^{3}$ candidate induced HR in $N$. benthamiana leaves, as revealed by the decolorized leaf tissue and electrolyte leakage (Fig. 2D and H). It did not induce any $\mathrm{HR}$ when coexpressed with $\mathrm{P}_{1,2,3}$ or $\mathrm{P}_{1,2,3,4} \mathrm{CP}$, with the exception of PIW-81A, which induced weak HR and low levels of electrolyte leakage (Fig. 2D and $\mathrm{H}$ ). This result is consistent with the responses of $L^{3}$ plants (delayed and diffused necrosis symptoms) to infection with PMMoV harboring the same CP (Fig. 2M). These results collectively indicate that the candidate gene is $L^{3}$.

\section{Cloning and functional analysis of $L$ alleles.}

The broad-spectrum nature of $L^{3}$ led us to hypothesize that $L^{1}$ and $L^{2}$ would have narrower resistance spectra and that $L^{4}$ would have a broader resistance spectrum than $L^{3}$. To test this hypothesis, we amplified and cloned $L^{3}$ homologs using common polymerase chain reaction (PCR) primers (described below) from several Capsicum plants: $C$. annuum cv. Verbeterde Glas (type accession of $L^{1}$ ) (Boukema 1980), C. annuum cv. Oonatsume (parental line of $L^{1 \mathrm{a}}$ accessions) (Sawada et al. 2004), C. annuum cv. KC780 ( $L^{1 \mathrm{a}}$-like resistance), C. frutescens cv. Tabasco (type accession of $L^{2}$ ) (Boukema 1980), $C$. frutescens LS 1839-2-4 ( $L^{2}$-like resistance), C. baccatum PI 439381-1-3 and KC 602 ( $L^{2}$-like resistance; designated to be $\left.L^{2 \mathrm{~b}}\right), C$. chinense $\mathrm{KC} 667$ ( $L^{1}$-like resistance; designated to be $L^{1 \mathrm{c}}$ ), C. chinense PI 152225 (type accession of $L^{3}$ ) (Boukema 
1980), C. chacoense PI 260429 (type accession of $L^{4}$ ) (Boukema 1982, 1984), and C. chacoense SA815 ( $L^{4}$-like resistance). The primers were designed based on conserved sequences in the $5^{\prime}$ end of $L^{3}$ and other $I 2$ homologs (Supple- mentary Fig. 4A) and in the $3^{\prime}$ end of $L^{3}$ and its homologs (details below). DNA fragments of approximately $4 \mathrm{~kb}$ were amplified from all Tobamovirus spp.-resistant Capsicum accessions but not from Tobamovirus spp.-susceptible accessions. Six $L^{3}$

A

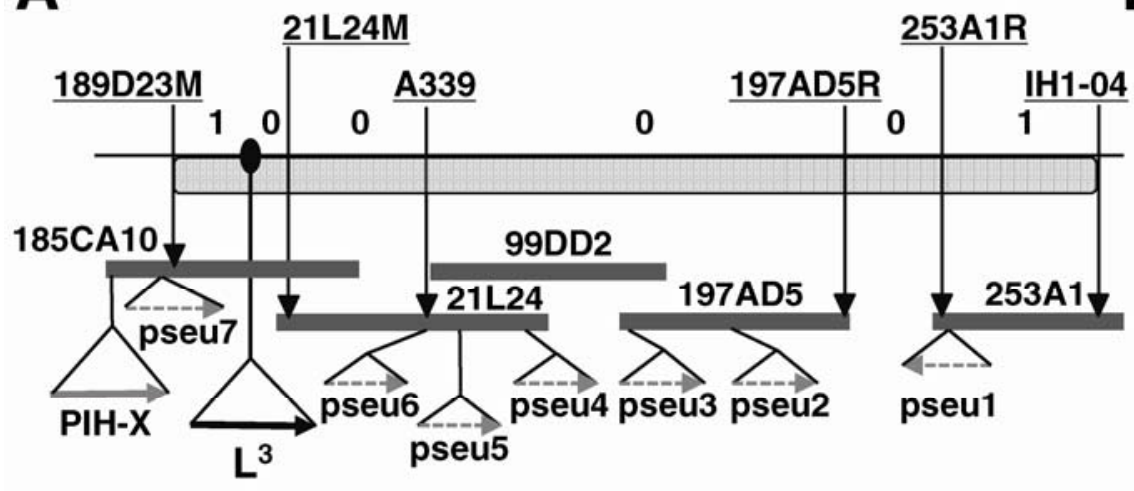

D


C

$L^{3}$



PIH-X 76.0/92.0 83.9/96.3 73.2/94.3 84.0/93.6 69.1/87.0 I2 $\quad 74.1 / 91.9 \quad 77.6 / 96.1 \quad 73.4 / 94.3 \quad 77.8 / 93.8 \quad 66.8 / 90.4$ R3a $\quad 71.6 / 92.3 \quad 79.4 / 95.0 \quad 74.7 / 93.6 \quad 80.9 / 93.8 \quad 64.5 / 87.2$

E
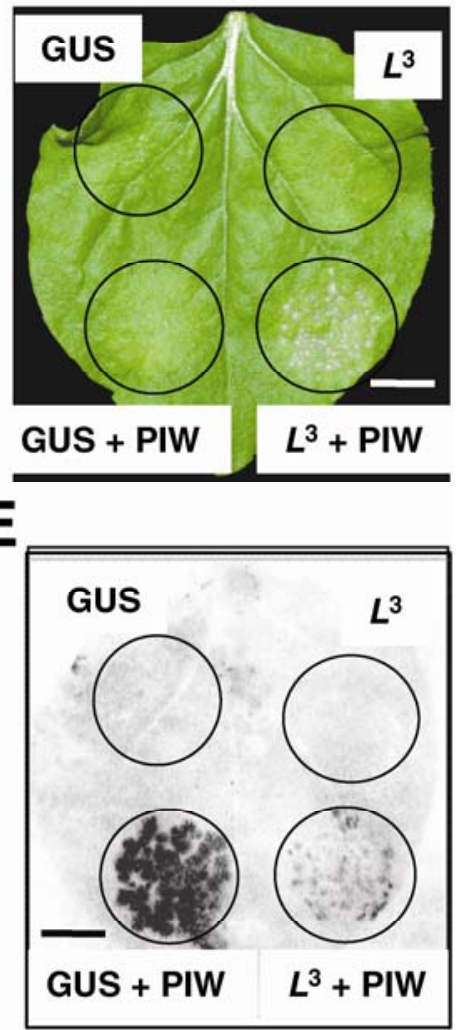

$\mathbf{F}$

Inoculated leaves Uninoculated

pBA-ev (line 1-3)
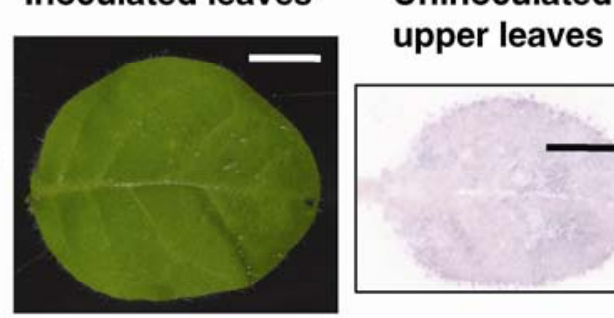

G
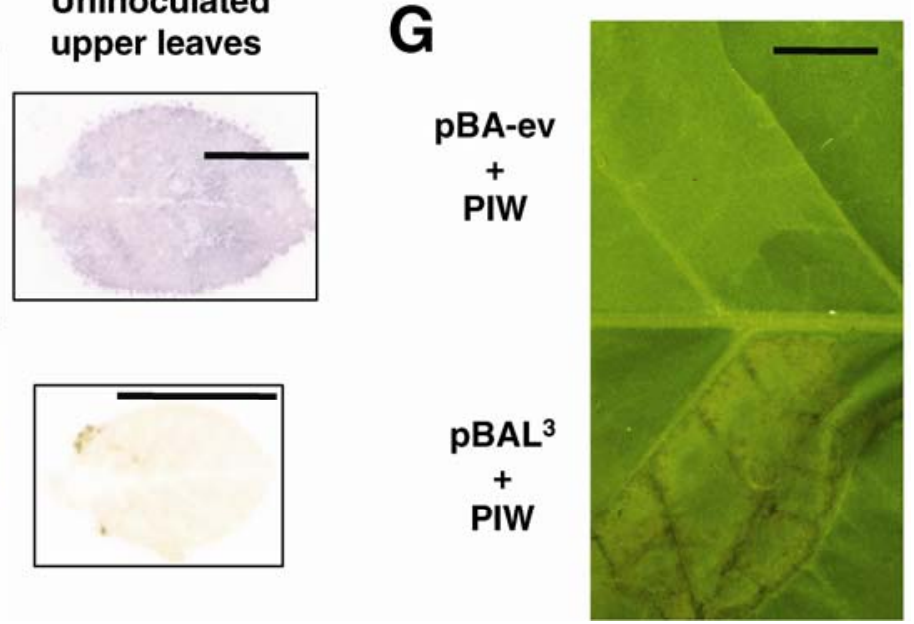

Fig. 1. Map-based cloning of $L^{3}$. A, Map of the $L$ locus. Dot on the horizontal line shows the position of the $L^{3}$ gene; numbers above the thick lines $(0$ or 1$)$ are the number of recombinants between $L^{3}$ resistance and the markers indicated with vertical arrows; vertical arrows show the positions of markers with their names underlined; a gray box represents the $L^{3}$ region; thick lines represent BAC clones with clone names; thick horizontal arrows represent $L^{3}$ (black) and its homolog, PIH-X (gray); dotted arrows represent pseudogenes that share homology with $L^{3}$. B, Schematic diagram of the transcript structure of $L^{3}$. Horizontal lines, exons; open arrow, coding sequence (CDS); lines angled upwards, introns. Sizes of introns are shown. C, Homology between $L^{3}$ and PIH$\mathrm{X}, \mathrm{I}$, or R3a proteins. Amino acid sequence identity or similarity are shown for full-length molecule (left); coiled-coil (CC); nucleotide-binding-Apaf-1, R proteins, and CED-4 (NB-ARC); and N- (LRR1) and C-terminal (LRR2) parts of leucine-rich repeat (LRR) domains. D, Functional analysis of cloned $L^{3}$ in Nicotiana benthamiana. Agrobacterium tumefaciens harboring $\beta$-glucuronidase (GUS)- or $L^{3}$-expressing constructs (pBAL ${ }^{3}$; bacterial absorbance at 600 nm $\left[\mathrm{A}_{600}\right]=0.5$ ) were infiltrated alone or with bacteria harboring a construct (pBTPIW) expressing the Pepper mild mottle virus (PMMoV)-Iw genome (PIW; bacterial $\left.\mathrm{A}_{600}=0.001\right)$. E, Immunodetection of PMMoV in a tissue blot. The leaf in $\mathrm{D}$ was subjected to detection by hammer blotting using anti-PMMoV antibody. F, Transgenic tobacco (N. tabacum) transformed with empty vector (pBA-ev) or pBAL ${ }^{3}$ showed susceptibility and resistance to Tomato mosaic virus (ToMV) infection, respectively. Photograph of inoculated leaves and immunodetection of ToMV in uninoculated upper leaves from representative lines are shown. G, Hypersensitive reaction induction by coexpression of $L^{3}$ and PMMoV genome in $N$. tabacum. A. tumefaciens harboring pBA-ev or pBAL ${ }^{3}$ (bacterial $\mathrm{A}_{600}=0.5$ ) was mixed with bacteria harboring pBTPIW (PIW; bacterial $\mathrm{A}_{600}=0.5$ ), infiltrated into $N$. tabacum leaves, and photographed 4 days postinfiltration. Scale bars in $\mathrm{D}$ to $\mathrm{G}$ indicate $1 \mathrm{~cm}$. 
homologs encoding $\mathrm{CNL}$ class $\mathrm{R}$ proteins were cloned from Capsicum plants containing $L^{1}, L^{1 \mathrm{a}}, L^{1 \mathrm{c}}, L^{2}, L^{2 \mathrm{~b}}$, and $L^{4}$. No intraspecies nucleotide sequence polymorphisms were found within the accessions showing the same resistance phenotype. The coding regions of the $L^{3}$ homologs consist of 3987 nucleotides (as does $L^{3}$ ), except for that from the $L^{1 \mathrm{c}}$ plant, which has a 6-bp insertion. The seven protein products of $L^{3}$ and its homologs share amino acid sequence identities of 97.4 to $99.6 \%$ (Supplementary Table 1).

Transient expression assays in $N$. benthamiana demonstrated that these $L^{3}$ homologs have HR-inducing functions when coexpressed with Tobamovirus CP (Fig. 2). The $L^{3}$ homolog from an $L^{1}$ plant responded to $\mathrm{CP}$ from $\mathrm{P}_{0} \mathrm{CP}$ but not to $\mathrm{P}_{1}$ or $\mathrm{P}_{1,2}$, and that from $L^{2}$ plants responded to $\mathrm{P}_{0}$ and $\mathrm{P}_{1}$ but not to $\mathrm{P}_{1,2}$ or $\mathrm{P}_{1,2,3}$ (Fig. 2B, C, F, and G). In contrast, the $L^{3}$ homolog from $L^{4}$ plants responded to all Tobamovirus CP tested except for the $\mathrm{P}_{1,2,3,4} \mathrm{CP}$ (Fig. 2E and I). The results indicate that the cloned $L^{3}$ homologs are indeed $L$ alleles and that the $L^{1}$ and $L^{2}$ alleles had a narrower recognition spectrum than $L^{3}$ and the $L^{4}$ allele had a broader recognition spectrum than $L^{3}$. The cloned $L^{3}$ homologs from $L^{1 a}$ plants induced HR against $\mathrm{P}_{0} \mathrm{CP}$, as $\operatorname{did} L^{1}$, and, in addition, induced weak HR against $\mathrm{P}_{1} \mathrm{CP}$ (Fig. 2J), being consistent with the reported reaction of $L^{1 \text { a }}$ plants, which exhibit vein necrosis on infection with $\mathrm{P}_{1}$ pathotype PaMMV (Sawada et al. 2004). The $L^{3}$ homologs from the $L^{1 \mathrm{c}}$ plant and $L^{2 \mathrm{~b}}$ plants induced responses indistinguishable from those induced by $L^{1}$ (Fig. 2K) and $L^{2}$ (Fig. 2L), respectively. These results indicate that $L$ gene alleles each encode single CNL class R proteins with different recognition spectra, which would determine the resistance spectra of plants the $L$ gene alleles originated from.
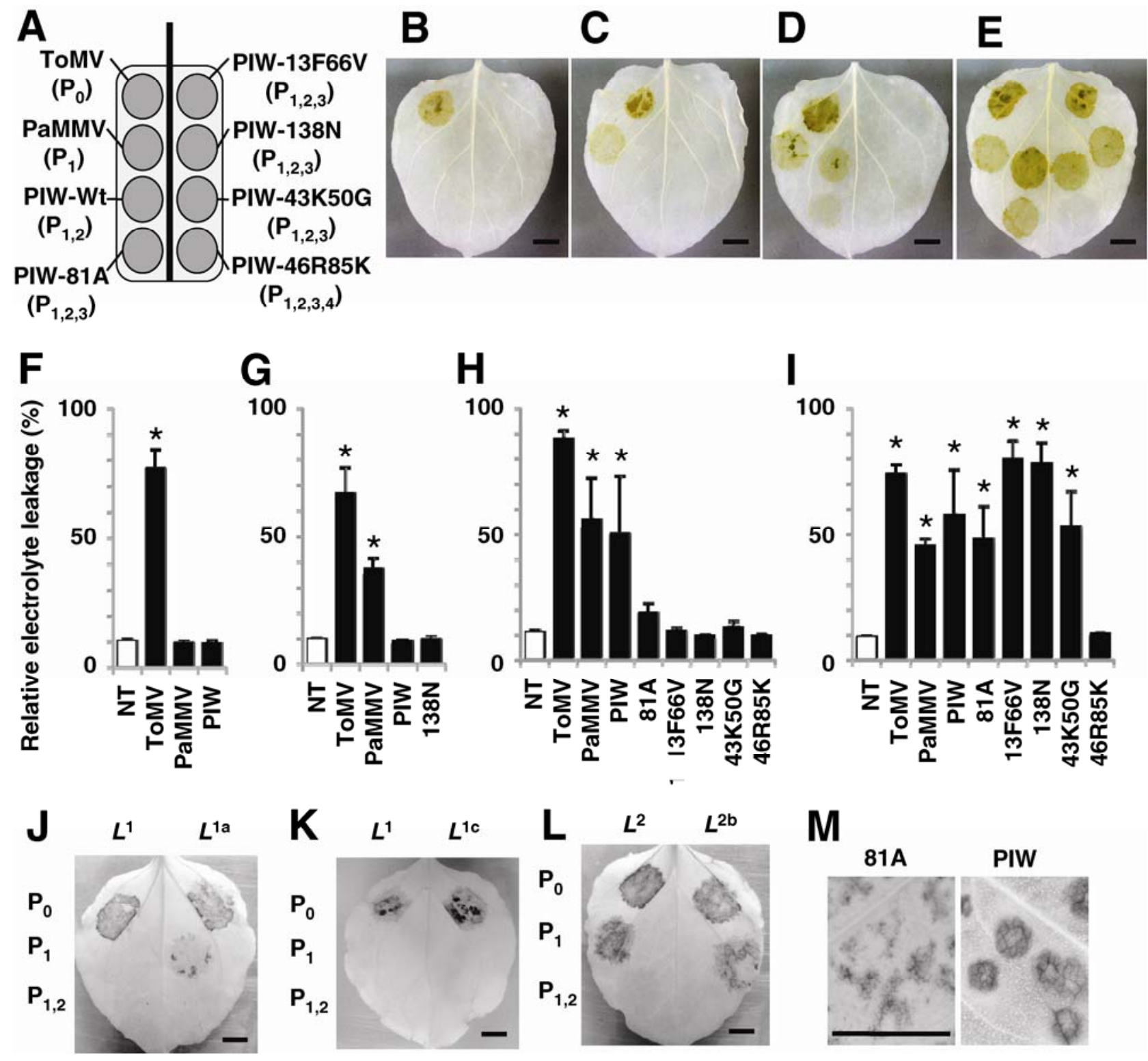

Fig. 2. Hierarchical interactions between $L$ genes and Tobamovirus coat protein (CP) are conditioned by single coiled-coil nucleotide-binding leucine-rich repeat proteins. A, Experimental settings for $\mathbf{B}$ to $\mathbf{E}$, in which eight different Tobamovirus CPs (pathotypes in parentheses) were coexpressed with $\mathbf{B}, L^{1} ; \mathbf{C}$, $L^{2} ; \mathbf{D}, L^{3} ;$ and $\mathbf{E}, L^{4}$ in Nicotiana benthamiana leaves. F to I, Electrolyte leakage was measured in nontreated $N$. benthamiana leaves (NT) and those in which the indicated Tobamovirus CPs and $L$ genes were coexpressed: $\mathbf{F}, L^{1} ; \mathbf{G}, L^{2} ; \mathbf{H}, L^{3} ;$ and $\mathbf{I}, L^{4}$ ) Ratios of leaked electrolyte to total electrolyte were calculated in two or more quadruplicate experiments. Means and standard deviations (error bars) from representative experiments are shown. Asterisks indicate statistically significant increase in electrolyte leakage $(P<0.05)$ compared with NT leaves in Dunnett's test. $\mathbf{J}$ to $\mathbf{L}$, Functional analysis of nonclassical $L$ genes: $\mathbf{J}$, $L^{1 \mathrm{a}}$ compared with $L^{1} ; \mathbf{K}, L^{1 \mathrm{c}}$ compared with $L^{1} ;$ and $\mathbf{L}, L^{2 \mathrm{~b}}$ compared with $L^{2} . N$. benthamiana leaves were agroinfiltrated as indicated. $\mathbf{M}, \mathrm{Responses}$ of $L^{3}$ plant to the infection with $\mathrm{P}_{1,2}$ (PIW) and $\mathrm{P}_{1,2,3}(81 \mathrm{~A})$ viruses. Plants were harvested 7 days post-mechanical inoculation, decolorized, and photographed. Scale bars in $\mathrm{B}$ to $\mathrm{E}$ and $\mathrm{J}$ to $\mathrm{M}$ indicate $1 \mathrm{~cm}$. 
Identification of $\mathrm{L}$ protein domains required for Tobamovirus specificity.

LRR domains have been shown to have roles in other R-proteins in the determination of recognition specificity. In the case of Potato virus $X$ (PVX) resistance gene $R x$, its CC-NB region has been shown to be interchangeable with that of GPA2, an $R x$ paralog conferring nematode resistance (Rairdan and Moffett 2006; van der Vossen et al. 2000). Although PIH-X, an $L^{3}$ paralog, has no known function, it is the closest relative to the $L$ gene reported herein (Fig. 1C). Therefore, we used it in a similar manner to GPA2 in the $R x$ study. To explore the L protein region determining Tobamovirus specificity, we constructed two chimeras between PIH-X and $L^{3}$ : Chimera A contained the CC-NB region from $P I H-X$ and the entire LRR from $L^{3}$ and chimera $\mathrm{B}$ contained the $\mathrm{CC}-\mathrm{NB}$ region and $\mathrm{N}$-terminal third of LRR, which is highly conserved among $L$ gene alleles, from $P I H-X$, and the C-terminal two-thirds of the LRR from $L^{3}$ (Fig. $3 \mathrm{~A})$. Chimera $\mathrm{A}$ induced $\mathrm{HR}$ against $\mathrm{P}_{0}$ and $\mathrm{P}_{1} \mathrm{CP}$, indicating that the CC-NB domains of $P I H-X$ can fulfill $\mathrm{HR}$ signaling (Fig. 3B). However, this chimera did not recognize $\mathrm{P}_{1,2} \mathrm{CP}$, suggesting that the $\mathrm{CC}$ or NB regions also influence broadspectrum recognition (Fig. 3B). Chimera $\mathrm{B}$ did not recognize even $\mathrm{P}_{0} \mathrm{CP}$, which is readily recognized by all of the $L$ gene alleles (Fig. 3B). The results suggest that the $\mathrm{N}$-terminal third of the LRR domains of $\mathrm{L}$ proteins has a fundamental role in

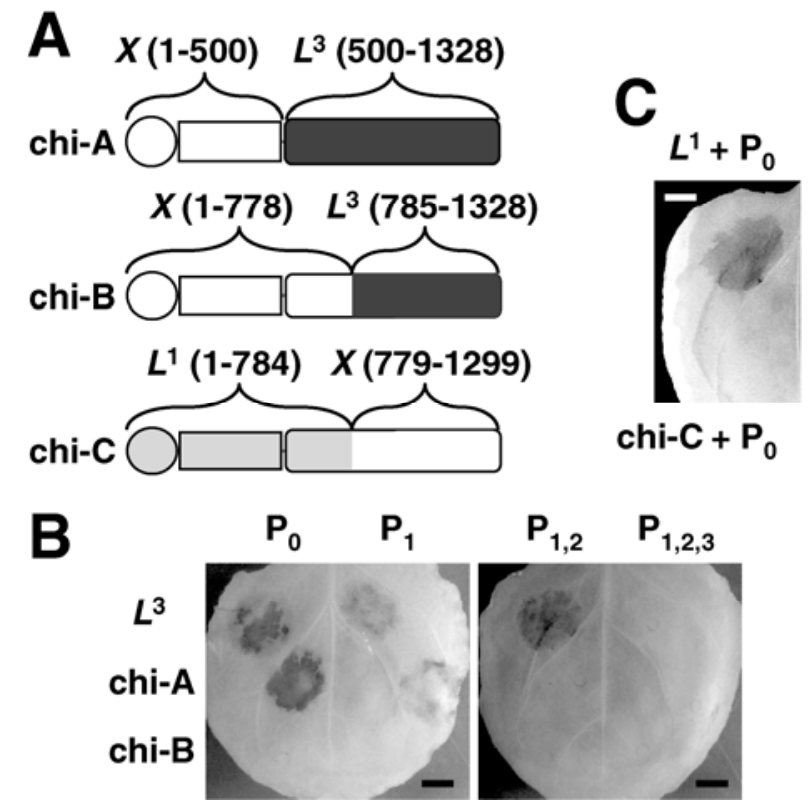

Fig. 3. Chimera analysis of Tobamovirus coat protein $(\mathrm{CP})$ recognition specificity of L proteins. A, Schematic representation of the structures of chimeras between PIH-X and $L^{3}$ (chi-A and chi-B) or between $L^{1}$ and PIH$\mathrm{X}$ (chi-C). B, Chimeras chi-A and chi-B were coexpressed with different Tobamovirus CPs in Nicotiana benthamiana leaves and observed for hypersensitive reaction. Expression of $L^{3}$ served as a control. C, Another chimera (chi-C) was coexpressed with $\mathrm{P}_{0} \mathrm{CP}$. Coexpression of $L^{1}$ and $\mathrm{P}_{0} \mathrm{CP}$ served as a positive control. Scale bars in $\mathrm{B}$ and $\mathrm{C}$ indicate $1 \mathrm{~cm}$. the recognition of Tobamovirus spp., including one in good folding of the protein, which is a prerequisite for protein function and stability. Another chimera (chimera C), comprising the $\mathrm{CC}, \mathrm{NB}$, and $\mathrm{N}$-terminal third of the LRR domain from $L^{1}$ and C-terminal two-thirds of the LRR from PIH-X (Fig. 3A), did not recognize any Tobamovirus $\mathrm{CP}$ (Fig. 3C), indicating that the C-terminal two-thirds of the $L$ LRR domain is also essential for Tobamovirus resistance.

\section{Analysis of LRR domain subregions required for broad-spectrum recognition.}

We next analyzed the chimeras between the $\mathrm{N}$-terminal region of $L^{1}$ and the C-terminal regions of the other $L$ genes to identify regions required for broad-spectrum recognition. Analysis of $L^{1}-L^{2}$ chimeras identified the central and C-terminal regions of LRR (Fig. 4A, subregions $\mathrm{b}$ and $\mathrm{f}$, respectively) to be important for recognition of the $\mathrm{P}_{1}$ pathotype by $L^{2}$ (Fig. 4A; Supplementary Fig. 5). Similarly, broad-spectrum recognition by $L^{3}$ required the central part of the LRR (subregions $\mathrm{c}$ and d) (Fig. $4 \mathrm{~A}, \mathrm{D}, \mathrm{E}$, and F). $L^{1}-L^{3}$ chimeras showed a reduced recognition spectrum as the $L^{3}$-derived region was narrowed down, suggesting that the combination of different LRR subregions is important for broad-spectrum recognition. $L^{2 \mathrm{~b}}$ and $L^{4}$ required a small central region (subregion e) of the LRR for their recognition spectra (Fig. 4A). Interestingly, $L^{2}$ and $L^{2 \mathrm{~b}}$, which have the same recognition spectrum, required different regions for their broad-spectrum resistance. Although $L^{2 \mathrm{~b}}$ conditioned the $\mathrm{P}_{1} \mathrm{CP}$-induced electrolyte leakage to a lesser extent than $L^{2}$ (Fig. 4B and C), HR-induction patterns were indistinguishable between $L^{2}$ and $L^{2 \mathrm{~b}}$ (Fig. 2L). However, they responded differently to chimera formation with $L^{1}$. The subregions $\mathrm{b}, \mathrm{c}$, and $\mathrm{f}$ of $L^{1}$ reduced the recognition spectrum of $L^{2}$ but not that of $L^{2 \mathrm{~b}}$, even enhancing the latter, as judged by electrolyte leakage measurements (Fig. 4B and C). Comparison of the $L^{1}-L^{2}$ and $L^{1}-L^{2 \mathrm{~b}}$ chimeras suggests that different combinations of LRR subregions can establish the same or very similar recognition spectra.

\section{Identification of amino acid residue critical for broad-spectrum recognition.}

Based on the chimera analysis, we aligned the amino acid residues to determine where one or more of the five allelic $\mathrm{L}$ proteins differ from each other (Fig. 5A). $L^{1 \mathrm{c}}$ and $L^{1 \mathrm{a}}$ proteins were excluded from the alignment because they were not characterized in the chimera analysis. Subregion e, which was sufficient to confer the broad-spectrum recognition of $L^{2 \mathrm{~b}}$ and $L^{4}$ to the chimeras, contains 15 amino acid differences, four of which are predicted to be solvent-exposed residues. We focused on one of them, the 1,127 th residue, which is histidine (His) in $L^{2 \mathrm{~b}}$, arginine (Arg) in $L^{4}$, and asparagine (Asn) in $L^{1}, L^{2}$, and $L^{3}$, because the strength of the basic nature of the amino acids parallels the recognition spectrum. We then changed His at 1,127 in the $L^{1}-L^{2 \mathrm{~b}}$ chimera (Fig. 5C) to Asn or Arg. The change to Asn impaired the recognition of $\mathrm{P}_{1}$ pathotype $\mathrm{CP}$; the $L^{1}-L^{2 \mathrm{~b}}$ chimera with the $\mathrm{H} 1127 \mathrm{~N}$ mutation reproducibly induced less visible $\mathrm{P}_{1} \mathrm{CP}$-induced $\mathrm{HR}$ and electrolyte leakage

Table 1. Tobamovirus coat proteins used in this study

\begin{tabular}{|c|c|c|c|c|}
\hline$\overline{\text { Name }}$ & Pathotype & Virus species & Strain & References \\
\hline ToMV & $\mathrm{P}_{0}$ & Tomato mosaic virus & $\mathrm{L}$ & Meshi et al. 1986 \\
\hline PaMMV & $\mathrm{P}_{1}$ & Paprika mild mottle virus & $\mathrm{J}$ & Hamada et al. 2003 \\
\hline PIW & $\mathrm{P}_{1,2}$ & Pepper mild mottle virus & Iw & Hamada et al. 2007 \\
\hline PIW-81A & $\mathrm{P}_{1,2,3}$ & Pepper mild mottle virus & $\mathrm{Oh}$ & Hamada et al. 2002; Sakamoto et al. 2008 \\
\hline PIW-13F66V & $\mathrm{P}_{1,2,3}$ & Pepper mild mottle virus & Is & Hamada et al. 2007 \\
\hline PIW-138N & $\mathrm{P}_{1,2,3}$ & Pepper mild mottle virus & I & Garcia-Luque et al. 1993; Sakamoto et al. 2008 \\
\hline PIW-43K50G & $\mathrm{P}_{1,2,3}$ & Pepper mild mottle virus & $\mathrm{Ij}$ & Tsuda et al. 1998; Sakamoto et al. 2008 \\
\hline PIW-46R85K & $\mathrm{P}_{1,2,3,4}$ & Pepper mild mottle virus & L4BV & Genda et al. 2007 \\
\hline
\end{tabular}


than the parental chimera (Fig. 5C, E, and G). In contrast, the change to Arg (H1127R mutation) conferred an $L^{4}$-like recognition spectrum on the chimera (Fig. 5D). These results indicate that the 1,127 th residue is important for the determination of the recognition spectrum of $\mathrm{L}$ proteins.

In the $L^{1}-L^{2 \mathrm{~b}}$ chimera with the $\mathrm{H} 1127 \mathrm{~N}$ mutation, the replacement of subregions $\mathrm{c}$ and d with those of $L^{3}$ conferred the ability to recognize $\mathrm{P}_{1}$ but not $\mathrm{P}_{1,2} \mathrm{CP}$ (Fig. 5F). This suggests that subregions $\mathrm{c}$ and $\mathrm{d}$ of $L^{3}$ have roles in broad-spectrum recognition (Fig. 4A) but are not sufficient for the recognition of $\mathrm{P}_{1,2}$ CP when combined with $L^{2 \mathrm{~b}}$ subregion e having the $\mathrm{H} 1127 \mathrm{~N}$ mutation. In addition to the critical 1,127th residue, the combination of amino acid sequences in the LRR domain is important for the determination of resistance spectra.

\section{DISCUSSION}

In this study, we first cloned the $L^{3}$ gene using a map-based method. We found only two genes, the $L^{3}$ gene and PIH-X, capable of encoding R-like proteins. The latter was shown to reside outside the region where the $L^{3}$ gene was mapped (Fig. 1A, the regions between the markers 189D23M and IH1-04). The functional analysis in $N$. benthamiana revealed that the cloned $L^{3}$ gene could drive resistance response to PMMoV (Fig. 1D and E) and reproduce the resistance spectrum of $C$. chinense containing the $L^{3}$ gene (Fig. 2D and H), confirming that the clone gene is the $L^{3}$ gene itself. Then we cloned the other six $L$ alleles using a homology-based method. Although we have not tested the linkage of these genes and resistance phenotypes in segregant populations, their high sequence identities to the $L^{3}$ gene support the fact that these cloned genes are alleles of the $L^{3}$ gene. They reproduce the recognition spectrum of the original Capsicum plants in functional analysis (Fig. 2), strongly suggesting that they are $L$ gene alleles. The functional analysis of the $L$ gene alleles answers a long-standing question: the $L$ locus consists of a single gene encoding an $\mathrm{R}$ protein with different recognition spectra but does not comprise a cluster of genes encoding $\mathrm{R}$ proteins with different recognition specificities.

In the proximity of the $L^{3}$ region, we found another CNLtype $R$-like gene, $P I H-X$. It shows high sequence identity to $L$ genes, especially in the $\mathrm{CC}$ domain and $\mathrm{N}$-terminal third of the LRR domain (Fig. 1C), but it did not have the function of inducing a Tobamovirus CP-dependent resistance response (data not shown). Therefore, we used it to identify the domains of the $L^{3}$ protein required for Tobamovirus specificity. Although

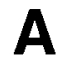

Spectrum of HR induction
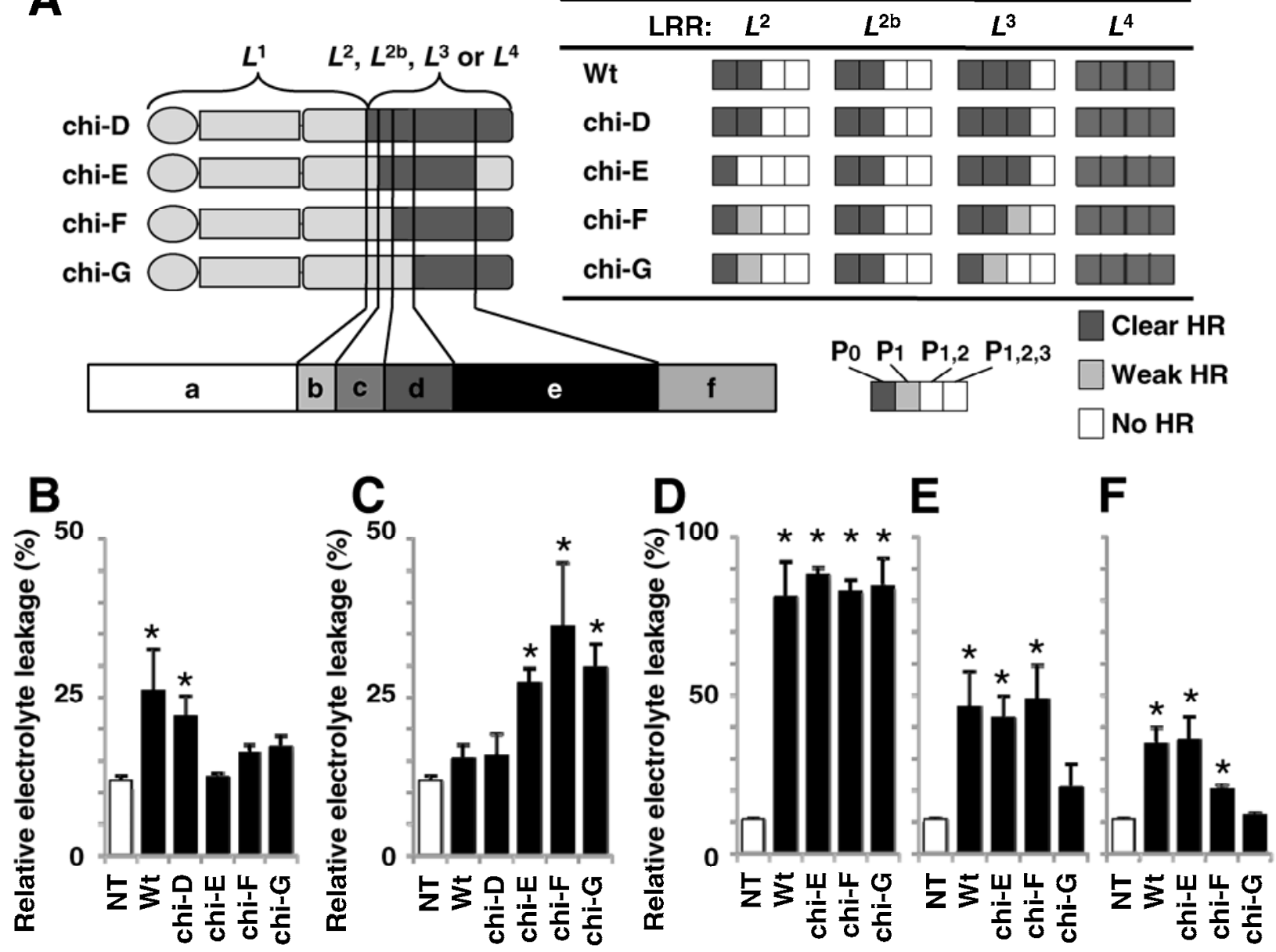

Fig. 4. Chimera analysis of Tobamovirus coat protein (CP) recognition spectrum of L proteins. A, Schematic representation of the structures of chimeras between $L^{1}$ and $L^{2}, L^{2 \mathrm{~b}}, L^{3}$, or $L^{4}$ and their recognition spectra. These chimeras were coexpressed with different Tobamovirus CPs and the hypersensitive reaction (HR) induction was observed. Based on the observations, the recognition spectrum of each chimera was determined and summarized in the table on the right. Origin of leucine-rich repeat (LRR) subregions (dark-gray boxes) is at the top $\left(L^{2}, L^{2 \mathrm{~b}}, L^{3}\right.$, and $\left.L^{4}\right)$. The recognition spectrum of each chimera is shown by the color of four successive squares, which indicates HR induction to $\mathrm{P}_{0}, \mathrm{P}_{1}, \mathrm{P}_{1,2}$, and $\mathrm{P}_{1,2,3}$, respectively, from the left. Dark gray, clearly visible HR; light gray, weak but visible HR; white, no visible HR; Wt, recognition spectra of parental $L$ alleles $\left(L^{2}, L^{2 \mathrm{~b}}, L^{3}\right.$, and $\left.L^{4}\right)$. Electrolyte leakage was measured in some chimeras and compared with the parental genes. $\mathbf{B}, L^{2}(\mathrm{~W})$ and chimeras (chi-D, chi-E, chi-F, and chi-G, as shown in A), coexpressed with $\mathrm{P}_{1} \mathrm{CP} ; \mathbf{C}, L^{2 \mathrm{~b}}$ (W) and chimeras (chi-D, chi-E, chi-F, and chi-G), coexpressed with $\mathrm{P}_{1} \mathrm{CP} ; \mathbf{D}$ to $\mathbf{F}, L^{3}(\mathrm{~W})$ and chimeras (chi-E,chi-F, and chi-G), coexpressed with $\mathbf{D}, \mathrm{P}_{0} ; \mathbf{E}, \mathrm{P}_{1}$; and $\mathbf{F}, \mathrm{P}_{1,2} \mathrm{CPs}$. Asterisks indicate statistically significant increase in electrolyte leakage $(P<0.05)$ compared with nontreated leaves (NT) in Dunnett's test. 
$P I H-X$ has no function assigned, unlike GPA2 (van der Vossen et al. 2000), it was shown to be able to produce a signal that leads to HR, suggesting its role in the resistance to some pathogen or pest (Fig. 3A).


Fig. 5. Mutational analysis of Tobamovirus coat protein (CP) recognition spectrum of $L$ proteins. A, Amino acids sequence differences among $L^{1}$, $L^{2}, L^{2 \mathrm{~b}}, L^{3}$, and $L^{4}$ in leucine-rich repeat subregions. The 1,127 th residue is boxed. B, Experimental setting for $\mathbf{C}$ to $\mathbf{F}$, the coexpression of $L^{2 \mathrm{~b}}$ with $\mathrm{P}_{1}$ $\mathrm{CP}$ as a control in the upper left; $\mathrm{CPs}$ from different pathotypes were coexpressed with the test constructs indicated. Responses to different CPs driven by $\mathbf{C}$, the chimera chi-G between $L^{1}$ and $L^{2 \mathrm{~b}} ; \mathbf{D}$, the same chimera with the H1127R mutation; E, the same chimera with the H1127N mutation; and $\mathbf{F}$, the mutant in $\mathrm{E}$ with subregions $\mathrm{c}$ and $\mathrm{d}$ replaced by those of $L^{3}$. G, Relative electrolyte leakage was calculated in nontreated Nicotiana benthamiana leaves (NT) and those in which $\mathrm{P}_{1} \mathrm{CP}$ was coexpressed with wild-type $L^{2 \mathrm{~b}}\left(L^{2 \mathrm{~b}}\right)$, chimera between $L^{1}$ and $L^{2 \mathrm{~b}}$ (chi-G), or the same chimera with $\mathrm{H} 1127 \mathrm{~N}$ mutation $(\mathrm{H} 1127 \mathrm{~N})$. Single asterisks indicate statistically significant increase in electrolyte leakage $(P<0.05)$ compared with NT leaves and a double asterisk indicates statistically significant difference $(P<0.05)$ between electrolyte leakage induced by chi-G and chi-G with $\mathrm{H} 1127 \mathrm{~N}$ substitution. Scale bars in $\mathrm{C}$ to F indicate $1 \mathrm{~cm}$.
The entire LRR domain of $\mathrm{L}$ proteins was shown to be required for Tobamovirus specificity (Fig. 3). Determination of pathogen specificity by the LRR domain of the R protein was also shown in the PVX resistance protein Rx (Rairdan and Moffett 2006). Unlike the $P I H-X-L^{3}$ chimera analysis, the conserved N-terminal half of the LRR domain of Rx can be replaced by the equivalent sequence of the GPA2 protein without the loss of PVX CP responsiveness (Rairdan and Moffett 2006). This would be because this subregion is highly conserved between Rx and GPA2 but not because it has no role in PVX resistance. A mutation therein was identified to enhance the activation of the Rx protein for defense signaling (Farnham and Baulcombe 2006). The N-terminal third of the LRR domain from PIH-X abolished the response of the PIH-X-L $\mathrm{L}^{3}$ chimera protein to any Tobamovirus CP (Fig. 3A). Because CC-NBARC domains of PIH-X are able to generate a resistance signal when combined with the LRR domain of $\mathrm{L}^{3}$, it is likely that this subregion (Fig. 4A, subregion a) has a role in the recognition of Tobamovirus CP. However, it is still possible that it is involved in the activation of the $\mathrm{L}^{3}$ protein for defense signaling.

The C-terminal two-thirds of L proteins were shown to determine the resistance spectrum (Figs. 4 and 5). The LRR domains of $\mathrm{R}$ proteins have been shown to determine pathogen race specificity in some $\mathrm{R}$ protein-pathogen combinations. The barley powdery mildew resistance proteins Mla1 and Mla6 recognize unrelated Avr effectors and the LRR and CT (C-terminal non-LRR) domains determine the specificity (Shen et al. 2003). The flax rust resistance proteins L5, L6, and L7 activate resistance response by physically interacting with some of the AvrL567 variants, and the determinant of the interaction was mapped to the LRR domain (Dodds et al. 2006). The flax L6 gene shows a slightly broader recognition spectrum of AvrL567 than the allelic $L 5$ gene. In turn, the $L 6$-driven resistance response is weaker than the L5-driven response for the AvrL567 variants commonly recognized by these two genes, suggesting that $L 6$ acquired broader recognition specificity in an evolutionary trade-off of the recognition of other AvrL567 variants. In contrast, the broad-spectrum pepper $L$ genes induce resistance response to the $\mathrm{P}_{0}$ pathotype as strongly as the $L^{1}$ gene, suggesting that pepper $\mathrm{L}$ proteins and flax $\mathrm{L}$ proteins employ distinct mechanisms for the broad-spectrum recognition of Avr effectors.

Among Tobamovirus pathotypes, $\mathrm{P}_{0}$ was readily recognized by all of the $L$ gene alleles. It induced significantly higher electrolyte leakage than any other pathotypes in $L^{2}$ and $L^{3}$ (Figs. $2 \mathrm{G}$ and $\mathrm{H}$ and $4 \mathrm{D}, \mathrm{E}$, and $\mathrm{F}$ ). In $L^{4}$, however, $\mathrm{P}_{1,2,3}$ gave rise to electrolyte leakage comparable with that of $\mathrm{P}_{0}$ (Fig. 2I). This difference in function would reflect the difference in molecular interaction between $\mathrm{L}$ proteins and CP. Such interaction remains to be studied but $\mathrm{P}_{0} \mathrm{CP}$ is expected to interact strongly with $\mathrm{L}$ proteins and be useful for future analysis.

The recognition spectrum of pepper $L$ proteins was shown to be determined by the combination of amino acids at different positions of the LRR domain (Fig. 4). We found that the basic nature at position 1,127 is important for a broad recognition spectrum and that amino acids at other positions also affect the recognition spectrum (Fig. 5). This finding led us to expect that the additive effect of Arg at 1,127 and other amino acid residues in different positions in $L^{3}$ should produce a new gene with a recognition spectrum broader than that of $L^{4}$. Therefore, we introduced the N1127R mutation into $L^{3}$ but the artificial mutant showed the same resistance spectrum as $L^{4}$ (data not shown). Although this attempt was not successful, a previous study is encouraging. Introduction of random mutations and phenotypic selection, or artificial evolution strategy, led to the isolation of $R x$ genes with broader resistance spectra (Farnham 
and Baulcombe 2006). Each of the four mutations rendered a broader resistance spectrum to $R x$ and, when combined, they showed additive or synergistic effects on the resistance spectrum of $R x$. Natural variation of $R x$ has not been reported except for $R \times 2$ and, therefore, the artificial evolution would be the best method to improve the performance of the Rx protein. In contrast, there are several variants of $\mathrm{L}$ proteins and we have obtained seven of them. A more intensive search for $L$ gene alleles and a detailed comparative analysis of them should lead us to obtain a new $L$ gene with a broader resistance spectrum.

In the chimera analysis, $\mathrm{CC}$ or $\mathrm{NB}$ domains were suggested to influence broad-spectrum recognition by the $\mathrm{L}^{3}$ protein (Fig. $3 \mathrm{~A})$. This results from the reduced activation capacity or the lesser signaling potential of the chimera A but it is also possible that the $\mathrm{CC}$ or NB domains have roles in the recognition of Avr effectors. The LRR has been shown to be important in determining recognition specificity (Dodds et al. 2006; Rairdan and Moffett 2006; Shen et al. 2003). Meanwhile, N-terminal domains, such as TIR or CC, were also shown to interact with some cofactors that were confirmed or proposed to be involved in the recognition of Avr effectors by $\mathrm{R}$ proteins (Collier and Moffett 2009; Moffett 2009). Recognition of Tobamovirus CP by L proteins may involve such a cofactor. It would be interesting to identify and compare the cofactors of $\mathrm{L}$ proteins and other homologous $\mathrm{R}$ proteins (I2-like proteins). This would help us understand the overall mechanism underlying the recognition of Tobamovirus $\mathrm{CP}$ by $\mathrm{L}$ proteins and rationally design new genes with a broader or different resistance spectrum.

\section{MATERIALS AND METHODS}

\section{Plants and viruses.}

Capsicum plants and N. benthamiana and N. tabacum plants were grown in pots containing a commercial soil mixture $(\mathrm{Sa}-$ kata Seed Co., Yokohama, Japan) in a glasshouse at $25 \pm 5^{\circ} \mathrm{C}$. Tobamovirus spp. and their CP genes used in this study are shown in Table 1. PMMoV-Iw (Hamada et al. 2007) was used for constructing the agroinfection vector. The PIW and PIW$81 \mathrm{~A}$ viruses were described by Hamada and associates (2002) and Sakamoto and associates (2008).

\section{Cloning and plasmid construction.}

The PCR primers and oligonucleotide linkers used in this study are shown in Supplementary Table 2.

$\mathrm{L}^{3}$ gene and PIH-X. BAC clones used for the cloning of $L^{3}$ were described previously (Tomita et al. 2008), and were sequenced using a shotgun method with more than 7.5 times coverage. The coding sequence of the $L^{3}$ candidate gene was amplified by PCR using Sse-L-F and L-Sal-R primers from BAC clone 185CA10, with PrimeSTAR GXL DNA polymerase (Takara Bio, Ohtsu, Japan). The PCR product was first cloned using a Zero-Blunt TOPO PCR cloning kit (Life Technologies, Carlsbad, CA, U.S.A.), sequenced, and then introduced into pBA, which had an A. thaliana actin 2 promoter (An et al. 1996; Kobayashi et al. 2006), a multicloning site (comprising XbaI, Sse8387I, KpnI, SalI, and BamHI restriction sites) in place of the GUS gene expression unit, the $35 \mathrm{~S}$ promoter, and hygromycin phosphotransferase coding region of pIG121-Hm (Akama et al. 1992), a pBI121-derivative. PIH-X was also identified in BAC clone 185CA10. Its coding sequence was amplified with Sse-X-F and X-Sal-R primers, using BAC clone 185CA10 as a template and PrimeSTAR GXL DNA polymerase. The PCR product was sequenced, and then introduced into $\mathrm{pBA}$ as described.

$\mathrm{L}^{3}$ homologs. We previously isolated partial fragments of $I 2$ homologs from $C$. chinense to develop genetic markers for mapping $L^{3}$ (Tomita et al. 2008). The fragment (nucleotide nos. 2,794 to 3,646$)$ of $L^{3}$ itself was too similar to its homolog from $C$. frutescens LS 1839-2-4 harboring $L^{2}$ (crossing counterpart used for mapping $L^{3}$ ) to develop a marker, suggesting that it was derived from the $L^{2}$ gene. Homologs of this fragment were amplified from Capsicum spp. C. annuum cv. Verbeterde Glas $\left(L^{1}\right), C$. annuum cv. $\operatorname{KC780}\left(L^{1 \mathrm{a}}\right), C$. frutescens cv. Tabasco $\left(L^{2}\right)$, and $C$. baccatum PI 439381-1-3 $\left(L^{2 \mathrm{~b}}\right)$ using primers LconF1 and LconR4. All of the homologs exhibited high homology and primers for 3'-rapid amplification of cDNA ends were designed from conserved regions (LconF3 and LconF4). The 3' ends of the coding sequences and UTR were amplified and cloned using RNA from the same plants as the templates. The nucleotide sequences of the $3^{\prime}$ part of the coding sequences and their close proximity are highly conserved among the five $L$ genes $\left(L^{3}, L^{1}, L^{2}, L^{1 \mathrm{a}}\right.$, and $\left.L^{2 \mathrm{~b}}\right)$. Many of the $I 2$ homologs, including characterized $R 3 a, L^{3}$, uncharacterized PIH-X, and pseudogenes found in the pepper chromosome, share the first 35 nucleotides in the $5^{\prime}$ terminus of the coding sequence. The coding sequences of $L^{3}$ homologs were amplified by PCR using Sse-L-F and L-Sal-R primers and PrimeSTAR GXL DNA polymerase. The PCR products were cloned, sequenced, and then introduced into $\mathrm{pBA}$ as described above. The true $3^{\prime}$ end sequences of $L^{1 \mathrm{c}}$ and $L^{4}$ were confirmed by sequencing 1,166-bp fragments amplified from genomic DNA of $C$. chinense KC667 and C. chacoense PI 260429, respectively, using $L^{3}-3782 \mathrm{~F}$ and $L^{3} \operatorname{expR}$ primers. As a Tobamovirus spp.-susceptible accession, $C$. annuum cv. Shosuke was used.

L genes chimera and mutants. Chimera A was constructed by replacing the Sse8387I-NheI fragment with a chimeric PIH$\mathrm{X}-L^{3}$ fragment amplified by recombinant PCR. The overlapping region is identical in both the upstream PIH-X fragment and downstream $L^{3}$ fragment. Chimeras $\mathrm{B}$ and $\mathrm{C}$ were constructed by replacing the NheI-SalI (nucleotide nos. 2,346 to 3,987 in $L^{3}$ and $L^{1}$ and 2,334 to 3,900 in PIH-X) between PIH$\mathrm{X}$ and $L^{3}$, and $L^{1}$ and PIH-X, respectively. Chimeras D and $\mathrm{E}$ (Fig. 5A) were constructed by replacing the NheI-SalI and EcoRI-SacI (nucleotide nos. 2,494 to 3,604 of $L^{3}$ ) fragments of $L^{1}$, respectively, with the equivalent fragments from $L^{2}, L^{2 \mathrm{~b}}, L^{3}$, or $L^{4}$. Chimeras $\mathrm{F}$ and $\mathrm{G}$ were constructed as follows; i) chimeric fragments between $L^{1}$ and $L^{2}, L^{2 \mathrm{~b}}, L^{3}$, or $L^{4}$ were amplified by recombinant PCR using primers designed against regions conserved among all $L$ alleles; and ii) chimeric fragments were cloned, sequenced, excised by EcoRI and SalI, and then replaced the corresponding fragment of pBA- $L^{1}$. The H1127N and H1127R mutations were introduced into the cloned chimeric fragment of $L^{1}-L^{2 \mathrm{~b}}$ using primers L-1127N-F and -R, and L-1127R-F and $-\mathrm{R}$, respectively. The mutated chimeric fragments (nucleotide nos. 2,393 to 3,987 of $L^{3}$ ) were cloned, sequenced, and introduced into pBA- $L^{1}$ as described. The H1127N mutation was also introduced into the chimera G-like $L^{3}-L^{2 \mathrm{~b}}$ chimeric fragment, in which LRR subregions c and d from $L^{3}$ were fused to subregions $\mathrm{E}$ and $\mathrm{F}$ from $L^{2 \mathrm{~b}}$. The resultant fragment was used to replace the EcoRI-SalI fragment of pBA-L ${ }^{1}$.

Agroinfection construct of PMMoV. A binary vector was constructed to express the PMMoV genome, resulting in PMMoV infection. PMMoV sequences were amplified using pPIW2 (Hamada et al. 2007) as a template. The NheI-EcoRI fragment $(5.3 \mathrm{~kb})$ of binary vector pBI121 (Jefferson et al. 1987) was replaced by a polylinker (NheI, HindIII, SacI, BamHI, SmaI, ApaI, SpeI, Acc65I, and EcoRI). The Nos-3' sequence, amplified using primers Apa-Nos3'F and Nos3'BsiR, was cloned, sequenced, excised by ApaI and BsiWI, and then introduced between the ApaI and Acc65I sites of the polylinker, resulting in $\mathrm{pBInos} 3^{\prime}$. A tandem $35 \mathrm{~S}$ promoter was generated by combining two PCR-amplified fragments (BamHIenhancer-core promoter-MunI, amplified using 35SpCapR and 
Bam35SpEnR, and SacI-enhancer-BglII, amplified using Sac35SpEnF and Bgl35SpEnF) and then cloned into pGreen0000 (Hellens et al. 2000), resulting in pGtan. The promoter was amplified and combined with a PMMoV cDNA 5' partial fragment using the following primers: NheT35F, 35SPM5'R, 35SPM5'F, and PM266-BHR. This fragment was introduced upstream of the Nos-3' sequence in pBInos3', resulting in pBTpiw5. The $3^{\prime}$ partial fragment of the PMMoV cDNA was amplified using PM3'-RzUp and BH-PM5412F, and then with BH-PM5412F and RzDn-Apa, to fuse with the ribozyme sequence (Liu et al. 2002). This fragment was introduced between the Nos-3' sequence and promoter-PMMoV 5' cDNA of pBTpiw5, resulting in pBTpiw5+3. The central part of the PMMoV cDNA was introduced from pPIW2 as a StuI-SpeI fragment into pBTpiw5+3, resulting in a plasmid with the fulllength PMMoV under the control of a tandem $35 \mathrm{~S}$ promoter, and named pBTPIW.

Tobamovirus $C P$ expression constructs. $\mathrm{CP}$ coding sequences of ToMV, PaMMV J strain, PIW, PIW-81A, PIW-13F66V, PIW-138N, and PIW-43K50G were PCR amplified. The coding sequence of PIW-46R85K CP was generated by recombinant PCR. Tobamovirus CP coding sequences were first cloned using a Zero-Blunt TOPO PCR cloning kit (Invitrogen), sequenced, and then introduced into a pGreen-based expression vector, pGT, which was constructed by introducing the above-mentioned ApaI-Nos 3' sequence-BsiWI fragment into pGtan.

\section{Transient expression assay.}

Transient expression assays (Bendahmane et al. 2000) were performed using $N$. benthamiana plants at the six- to nine-leaf stages in a growth chamber at $24^{\circ} \mathrm{C}$ with illumination for 16 h/day. Expression vectors were introduced into Agrobacterium tumefaciens LBA4404 ( $L$ genes constructs) or EHA105 (virus and CP constructs). $N$. benthamiana leaves were agroinfiltrated (absorbance at $600 \mathrm{~nm}\left[\mathrm{~A}_{600}\right]=0.2$ to 0.5 for $L$ genes constructs and CP constructs; $\mathrm{A}_{600}=0.001$ for $\mathrm{pBTPIW}$ ), then harvested 4 days postinfiltration. The harvested leaves were decolorized in $99.5 \%$ (overnight) and $70 \%$ (1 to 2 days) ethanol, and photographed such that weak HR can be observed clearly. Plant leaves infiltrated with Agrobacterium tumefaciens harboring pBTPIW were examined for virus spread by hammer blotting.

\section{Electrolyte leakage measurement.}

Electrolyte leakage was measured as previously described (Kim et al. 2003). Briefly, five leaf discs (6 $\mathrm{mm}$ in diameter) were cut out at 3 days postagroinfiltration and immersed for 12 $\mathrm{h}$ in $0.4 \mathrm{M}$ sorbitol. The conductivity of the sorbitol solution was measured before (leaked electrolyte) and after boiling for 5 min with the leaf discs (total electrolyte) and shown as a percentage of leaked to total electrolyte. The triplicate or quadruplicate experiments were repeated at least twice and the representative results are shown. The results were statistically analyzed for the increase in electrolyte leakage compared with that in nontreated leaves by Dunnett's test (Dunnett 1964; Dunnett and Crisafio 1955) using the MEPHAS online service (provided by the Genome Information Research Center, Osaka University, Japan).

\section{Plant transformation and resistance assay.}

Tobacco (N. tabacum, cv. SR-1) plants were grown aseptically on vitamin- and hormone-free Murashige and Skoogagar medium (Murashige and Skoog 1962). Tobacco leaf discs were then subjected to transformation as described (Horsch et al. 1985) with A. tumefaciens LBA4404 harboring pBA-ev or $\mathrm{pBAL}^{3}$. Kanamycin-resistant $\left(\mathrm{Km}^{\mathrm{r}}\right)$ shoots were analyzed by PCR for the presence of ACT2 promoter-driven $L^{3}$ expression.
Plantlets were transferred to soil after root formation. In all, four and 13 independent $\mathrm{T}_{0}$ lines transformed with $\mathrm{pBA}-\mathrm{ev}$ and $\mathrm{pBAL}^{3}$, respectively, gave $\mathrm{Km}^{\mathrm{r}}$ progenies, three each of which were subjected to the resistance assay against ToMV and reverse-transcription PCR analysis for transgene expression. Two leaves each of the plants were mechanically inoculated with purified ToMV at $10 \mu \mathrm{g} / \mathrm{ml}$ and examined for the spread of ToMV by hammer blotting of uninoculated upper leaves (14 days postinoculation). RNA was extracted from the test plants and reverse-transcribed using oligo-dT primer at $42^{\circ} \mathrm{C}$ for 30 min using PrimeScript reverse transcriptase (Takara Bio). The cDNA was analyzed by PCR for ACT2 promoter-driven $L^{3}$ or endogenous EF1 $\alpha$ (internal reference) under the following reaction condition: $95^{\circ} \mathrm{C}$ for $2 \mathrm{~min}$ for initial denaturation and 25 cycles of $94^{\circ} \mathrm{C}$ for $30 \mathrm{~s}, 60^{\circ} \mathrm{C}$ for $30 \mathrm{~s}$, and $72^{\circ} \mathrm{C}$ for $40 \mathrm{~s}$ for amplification using primers and ExTaq DNA polymerase (Takara Bio).

\section{Detection of virus infection.}

Hammer blotting was performed as described previously (Hamada et al. 2008) using anti-PMMoV antiserum or antiToMV serum (Japan Plant Protection Association, Ushiku, Japan).

\section{ACKNOWLEDGMENTS}

We thank T. Sasakuma (Kihara Institute for Biological Research, Yokohama City University, Yokohama, Japan), S. Momma (National Institute of Vegetables and Tea Science, Mie, Japan), and O. Nunomura (Japan Horticultural Production and Research Institute, Chiba, Japan) for generous gifts of their Capsicum collections; P. Moffett for comments on the manuscript; D. Murphy for English correction; and K. Obara for technical assistance. This work was supported in part by the government of Iwate prefecture and in part by a Grant-in-Aid for Scientific Research (B) no. 21380032 from the Japan Society for the Promotion of Science to $\mathrm{K}$ Kobayashi.

\section{LITERATURE CITED}

Akama, K., Shiraishi, H., Ohta, S., Nakamura, K., Okada, K., and Shimura, Y. 1992. Efficient transformation of Arabidopsis thaliana: Comparison of the efficiencies with various organs, plant ecotypes and Agrobacterium strains. Plant Cell Rep. 12:7-11.

An, Y. Q., McDowell, J. M., Huang, S., McKinney, E. C., Chambliss, S., and Meagher, R. B. 1996. Strong, constitutive expression of the Arabidopsis ACT2/ACT8 actin subclass in vegetative tissues. Plant J. 10:107121.

Antignus, Y., Lachman, O., Pearlsman, M., Maslenin, L., and Rosner, A. 2008. A new pathotype of Pepper mild mottle virus (PMMoV) overcomes the $L^{4}$ resistance genotype of pepper cultivars. Plant Dis. 92:1033-1037.

Bendahmane, A., Querci, M., Kanyuka, K., and Baulcombe, D.C. 2000. Agrobacterium transient expression system as a tool for the isolation of disease resistance genes: Application to the $R x 2$ locus in potato. Plant $\mathrm{J}$. 21:73-81

Berzal-Herranz, A., de la Cruz, A., Tenllado, F., Diaz-Ruiz, J. R., Lopez, L., Sanz, A. I., Vaquero, C., Serra, M. T., and Garcia-Luque, I. 1995. The Capsicum $L^{3}$ gene-mediated resistance against the tobamoviruses is elicited by the coat protein. Virology 209:498-505.

Boukema, I. W. 1980. Allelism of genes controlling resistance to TMV in Capsicum L. Euphytica 29:433-439.

Boukema, I. W. 1982. Resistance to a new strain of TMV in Capsicum chacoense Hunz. Capsicum News1. 1:49-51.

Boukema, I. W. 1984. Resistance to TMV in Capsicum chacoense Hunz. is governed by allele of the L-locus. Capsicum Newsl. 3:47-48.

Chisholm, S. T., Coaker, G., Day, B., and Staskawicz, B. J. 2006. Hostmicrobe interactions: Shaping the evolution of the plant immune response. Cell 124:803-814.

Collier, S. M., and Moffett, P. 2009. NB-LRRs work a "bait and switch" on pathogens. Trends Plant Sci. 14:521-529.

Cooley, M. B., Pathirana, S., Wu, H. J., Kachroo, P., and Klessig, D. F. 2000. Members of the Arabidopsis HRT/RPP8 family of resistance genes confer resistance to both viral and oomycete pathogens. Plant Cell 12:663-676. 
de la Cruz, A., Lopez, L., Tenllado, F., Diaz-Ruiz, J. R., Sanz, A. I., Vaquero, C., Serra, M. T., and Garcia-Luque, I. 1997. The coat protein is required for the elicitation of the Capsicum $L^{2}$ gene-mediated resistance against the tobamoviruses. Mol. Plant-Microbe Interact. 10:107113.

Dodds, P. N., Lawrence, G. J., Catanzariti, A. M., Teh, T., Wang, C. I., Ayliffe, M. A., Kobe, B., and Ellis, J.G. 2006. Direct protein interaction underlies gene-for-gene specificity and coevolution of the flax resistance genes and flax rust avirulence genes. Proc. Natl. Acad. Sci. U.S.A. 103:8888-8893.

Dunnett, C. W. 1964. New tables for multiple comparisons with a control. Biometrics 20:482-491.

Dunnett, C. W., and Crisafio, R. 1955. The operating characteristics of some official weight variation tests for tablets. J. Pharm. Pharmacol. 7:314-327.

Farnham, G., and Baulcombe, D. C. 2006. Artificial evolution extends the spectrum of viruses that are targeted by a disease-resistance gene from potato. Proc. Natl. Acad. Sci. U.S.A. 103:18828-18833.

Garcia-Luque, I., Ferrero, M. L., Rodriquez, J. M., Alonso, E., de la Cruz, A., Sanz, A. I., Vaquero, C., Serra, M. T., and Diaz-Ruiz, J. R. 1993. The nucleotide sequence of the coat protein genes and $3^{\prime}$ non-coding regions of two resistance-breaking tobamoviruses in pepper shows that they are different viruses. Arch. Virol. 131:75-88.

Genda, Y., Kanda, A., Hamada, H., Sato, K., Ohnishi, J., and Tsuda, S. 2007. Two amino acid substitutions in the coat protein of Pepper mild mottle virus are responsible for overcoming the L(4) gene-mediated resistance in Capsicum spp. Phytopathology 97:787-793.

Gilardi, P., Garcia-Luque, I., and Serra, M. T. 2004. The coat protein of tobamovirus acts as elicitor of both $L^{2}$ and $L^{4}$ gene-mediated resistance in Capsicum. J. Gen. Virol. 85:2077-2085.

Hamada, H., Takeuchi, S., Kiba, A., Tsuda, S., Hikichi, Y., and Okuno, T. 2002. Amino acid changes in Pepper mild mottle virus coat protein that affect $L^{3}$ gene-mediated resistance in pepper. J. Gen. Plant Pathol 68:155-162.

Hamada, H., Takeuchi, S., Morita, Y., Sawada, H., Kiba, A., and Hikichi, Y. 2003. Characterization of Paprika mild mottle virus first isolated in Japan. J. Gen. Plant Pathol. 69:199-204.

Hamada, H., Tomita, R., Iwadate, Y., Kobayashi, K., Munemura, I., Takeuchi, S., Hikichi, Y., and Suzuki, K. 2007. Cooperative effect of two amino acid mutations in the coat protein of Pepper mild mottle virus overcomes $L^{3}$-mediated resistance in Capsicum plants. Virus Genes 34:205-214.

Hamada, H., Matsumura, H., Tomita, R., Terauchi, R., Suzuki, K., and Kobayashi, K. 2008. SuperSAGE revealed different classes of early resistance response genes in Capsicum chinense plants harboring $\mathrm{L}^{3}$ resistance gene infected with Pepper mild mottle virus. J. Gen. Plant Pathol. 74:313-321.

Hellens, R. P., Edwards, E. A., Leyland, N. R., Bean, S., and Mullineaux, P. M. 2000. pGreen: A versatile and flexible binary Ti vector for Agrobacterium-mediated plant transformation. Plant Mol. Biol. 42:819832 .

Horsch, R. B., Fry, J. E., Hoffmann, N. L., Wallroth, M., Eichholtz, D., Rogers, S. G., and Fraley, R. T. 1985. A simple method for transferring genes into plants. Science 227:1229-1231.

Huang, S., van der Vossen, E. A., Kuang, H., Vleeshouwers, V. G., Zhang, N., Borm, T. J., van Eck, H. J., Baker, B., Jacobsen, E., and Visser, R. G. 2005. Comparative genomics enabled the isolation of the $R 3 a$ late blight resistance gene in potato. Plant J. 42:251-261.

Jefferson, R. A., Kavanagh, T. A., and Bevan, M. W. 1987. GUS fusions: Beta-glucuronidase as a sensitive and versatile gene fusion marker in higher plants. EMBO (Eur. Mol. Biol. Organ.) J 6:3901-3907.

Jones, J. D., and Dangl, J. L. 2006. The plant immune system. Nature 444:323-329

Kim, M., Ahn, J. W., Jin, U. H., Choi, D., Paek, K. H., and Pai, H. S. 2003. Activation of the programmed cell death pathway by inhibition of proteasome function in plants. J. Biol. Chem. 278:19406-19415.

Kobayashi, K., Munemura, I., Hinata, K., and Yamamura, S. 2006. Bisexual sterility conferred by the differential expression of barnase and barstar:
A simple and efficient method of transgene containment. Plant Cell Rep. 25:1347-1354.

Liu, Y., Schiff, M., Marathe, R., and Dinesh-Kumar, S. P. 2002. Tobacco Rar1, EDS1 and NPR1/NIM1 like genes are required for $N$-mediated resistance to Tobacco mosaic virus. Plant J. 31:415-429.

Matsumoto, K., Sawada, H., Matsumoto, K., Hamada, H., Yoshimoto, E. Ito, T., Takeuchi, S., Tsuda, S., Suzuki, K., Kobayashi, K., Kiba, A., Okuno, T., and Hikichi, Y. 2008. The coat protein gene of tobamovirus $\mathrm{P}(0)$ pathotype is a determinant for activation of temperature-insensitive L (1a )-gene-mediated resistance in Capsicum plants. Arch. Virol 153:645-50

McHale, L., Tan, X., Koehl, P., and Michelmore, R. W. 2006. Plant NBSLRR proteins: Adaptable guards. Genome Biol. 7:212.

Meshi, T., Ishikawa, M., Motoyoshi, F., Semba, K., and Okada, Y. 1986. In vitro transcription of infectious RNAs from full-length cDNAs of tobacco mosaic virus. Proc. Natl. Acad. Sci. U.S.A. 83:5043-5047.

Moffett, P. 2009. Mechanisms of recognition in dominant $R$ gene mediated resistance. Adv. Virus Res. 75:1-33.

Murashige, T., and Skoog, F. 1962. A revised medium for rapid growth and bio-assays with tobacco tissue cultures. Physiol. Plant. 15:473-497.

Ori, N., Eshed, Y., Paran, I., Presting, G., Aviv, D., Tanksley, S., Zamir, D., and Fluhr, R. 1997. The I2C family from the wilt disease resistance locus $I 2$ belongs to the nucleotide binding, leucine-rich repeat superfamily of plant resistance genes. Plant Cell 9:521-532.

Rairdan, G. J., and Moffett, P. 2006. Distinct domains in the ARC region of the potato resistance protein $R x$ mediate LRR binding and inhibition of activation. Plant Cell 18:2082-2093

Sakamoto, M., Tomita, R., Hamada, H., Iwadate, Y., Munemura, I., and Kobayashi, K. 2008. A primer-introduced restriction analysis-PCRbased method to analyse Pepper mild mottle virus populations in plants and field soil with respect to virus mutations that break $L^{3}$ gene-mediated resistance of Capsicum plants. Plant Pathol. 57:825-833.

Sawada, H., Takeuchi, S., Hamada, H., Kiba, A., Matsumoto, M., and Hikichi, Y. 2004. A new Tobamovirus-resistance gene, $L^{\text {1a }}$, of sweet pepper (Capsicum annum L.). J. Jpn. Soc. Hortic. Sci. 73:552-557.

Sekine, K. T., Kawakami, S., Hase, S., Kubota, M., Ichinose, Y., Shah, J., Kang, H. G., Klessig, D. F., and Takahashi, H. 2008. High level expression of a virus resistance gene, RCY1, confers extreme resistance to Cucumber mosaic virus in Arabidopsis thaliana. Mol. Plant-Microbe Interact. 21:1398-1407.

Shen, Q. H., Zhou, F., Bieri, S., Haizel, T., Shirasu, K., and SchulzeLefert, P. 2003. Recognition specificity and RAR1/SGT1 dependence in barley Mla disease resistance genes to the powdery mildew fungus. Plant Cell 15:732-744

Simons, G., Groenendijk, J., Wijbrandi, J., Reijans, M., Groenen, J., Diergaarde, P., Van der Lee, T., Bleeker, M., Onstenk, J., de Both, M., Haring, M., Mes, J., Cornelissen, B., Zabeau, M., and Vos, P. 1998. Dissection of the Fusarium $I 2$ gene cluster in tomato reveals six homologs and one active gene copy. Plant Cell 10:1055-1068.

Tomita, R., Murai, J., Miura, Y., Ishihara, H., Liu, S., Kubotera, Y., Honda, A., Hatta, R., Kuroda, T., Hamada, H., Sakamoto, M., Munemura, I., Nunomura, O., Ishikawa, K., Genda, Y., Kawasaki, S., Suzuki, K., Meksem, K., and Kobayashi, K. 2008. Fine mapping and DNA fiber FISH analysis locates the tobamovirus resistance gene $L^{3}$ of Capsicum chinense in a 400-kb region of R-like genes cluster embedded in highly repetitive sequences. Theor. Appl. Genet. 117:1107-1118.

Tsuda, S., Kirita, M., and Watanabe, Y. 1998. Characterization of a Pepper mild mottle tobamovirus strain capable of overcoming the $L^{3}$ gene-mediated resistance, distinct from the resistance-breaking Italian isolate. Mol. Plant-Microbe Interact. 11:327-331.

van der Biezen, E. A., and Jones, J. D. 1998. The NB-ARC domain: A novel signalling motif shared by plant resistance gene products and regulators of cell death in animals. Curr. Biol. 8:R226-227.

van der Vossen, E. A., van der Voort, J. N., Kanyuka, K., Bendahmane, A., Sandbrink, H., Baulcombe, D. C., Bakker, J., Stiekema, W. J., and Klein-Lankhorst, R. M. 2000. Homologues of a single resistance-gene cluster in potato confer resistance to distinct pathogens: A virus and a nematode. Plant J. 23:567-576. 